\title{
Penerapan Algoritma Genetika Untuk Optimasi Penempatan Buku Perpustakaan STIKOM Binaniaga
}

Oleh

\author{
: Frans Winowatan
}

\begin{abstract}
Abstrak
Perpustakaan ialah sebuah ruangan, bagian sebuah gedung, ataupun gedung itu sendiri yang digunakan untuk menyimpan buku dan terbitan lainnya yang biasanya disimpan menurut tata susunan tertentu untuk digunakan pembaca, bukan untuk dijual. Penempatan Buku di dalam rak perpustakaan harus bisa seoptimal mungkin untuk mempermudah dalam hal mencari buku. Tujuan dari penelitian ini adalah untuk memperoleh pola yang tepat untuk menentukan urutan posisi buku yang sesuai subjek buku dengan menggunakan metode algoritma genetika. Dengan memasukkan inputan berupa data buku kode rak buku dan jumlah buku yang ada, proses optimasi akan menemukan pola penempatan buku berdasarkan fitness, yaitu semakin tepat dalam penempatan buku. Untuk mendapatkan output pada algoritma genetika, diperlukan beberapa tahapan yaitu dimulai dari proses inisialisasi populasi awal, pencarian nilai fitness, seleksi, crossover, mutasi dan lainnya. Pola atau aturan yang dihasilkan dari proses algoritma genetika pada permasalahan penempatan buku memberikan solusi berupa nilai fitness adalah 0.0080 , dengan pola penempatan buku yaitu 16-8-6-10-18-13-7-14-15-17-3-12-2-1-9-11-4-5. Optimasi penempatan buku ini mendapatkan hasil bahwa penempatan buku berdasarkan algoritma genetika dibandingkan dengan penempatan buku data awal memiliki tingkat optimal sebesar 31.61574. Nilai RMSE tersebut menunjukan nilai eror dari metode yang digunakan, nilai tersebut diperoleh dengan membandingkan posisi buku algoritma genetika dengan posisi buku pada data awal dengan urutan posisi buku sesuai dengan jumlah buku. Sementara tingkat ketepatan prediksi metode algoritma genetika sebesar $68.38 \%$. nilai ketepatan prediksi tersebut dapat dijadikan referensi untuk optimasi penempatan buku.
\end{abstract}

Kata Kunci : Algoritma Genetika, Perpustakaan, RMSE

\section{Pendahuluan}

Perpustakaan perguruan tinggi merupakan perpustakaan milik universitas, institut, akademi, yang digunakan sebagai sarana penunjang pelaksanaan tugas-tugas yang tercantum dalam Tri Darma Perguruan Tinggi. Perpustakaan perguruan tinggi juga sering disebut sebagai jantung perguruan tinggi. Batasan ruangan ialah sebagai ruangan, bagian sebuah gedung, ataupun gedung itu sendiri yang digunakan untuk menyimpan buku dan terbitan lainnya yang biasanya disimpan menurut tata susunan tertentu untuk digunakan pembaca, bukan untuk dijual (Basuki, 1993, hal. 3).

Fungsi perpustakaan adalah sebagai tempat penyimpanan karya manusia, informasi, rekreasi, pendidikan dan kultural. Hal tersebut berkaitan dengan tugas perpustakaan perguruan tinggi yaitu mengelola koleksi perpustakaan yang mencakup kegiatan pemilihan dan pengadaan bahan pustaka, pengolahan, pelayanan, dan perawatan. Koleksi yang telah disediakan oleh bagian petugas perpustakaan belum dapat ditayangkan langsung kepada para pengguna perpustakaan.

Sebagai sebuah Institusi Pendidikan, STIKOM memiliki perpustakaan, sebagai sumber pembelajaran dan sumber aktivitas intelektual yang sangat penting bagi segenap sivitas akademika dalam mendukung terciptanya program Tridharma Perguruan Tinggi. Berpijak pada hakikat layanan perpustakaan, dengan berorientasi kepada pemakai maka layanan perpustakaan diselenggarakan dengan tujuan untuk membantu memenuhi kebutuhan informasi pemakai secara tepat dan akurat, yaitu melalui penyediaan bahan pustaka dan penyediaan 
sarana penelusurannya. Secara umum, layanan perpustakaan terdiri atas Sistem Pelayanan Terbuka (Open Access), Sistem Pelayanan Tertutup (Closed Access).

Layanan perpustakaan di STIKOM menggunakan sistem layanan terbuka, dimana pemustaka dapat langsung menuju jajaran rak untuk memanfaatkan koleksi. Koleksi tercetak dikelompokkan dengan System Dewey Decimal (DDC), namun dalam hal penentuan posisi dan urutan penempatan koleksi buku didasarkan pada rak yang tersedia dalam pengelompokkan urutan posisi buku. Selain itu, Katalog perpustakaan dapat diakses secara Online Public Access Catalog (OPAC) baik di dalam perpustakaan maupun melalui jaringan kampus.

Terlebih dahulu koleksi tersebut harus diolah agar dapat memudahkan para pengguna dalam menemukan informasi yang dibutuhkan. Selain itu juga memudahkan para petugas perpustakaan untuk mengetahui dan mengontrol bahan pustaka yang digunakan oleh para pengguna. Pengolahan bahan pustaka mencakup kegiatan pengkatalogan dan pengklasifikasian. Katalog perpustakaan adalah daftar buku dalam sebuah perpustakaan atau dalam sebuah koleksi, daftar menunjukkan adanya susunan menurut prinsip tertentu sedangkan buku mencakup arti buku dalam arti luas. Klasifikasi adalah pengelompokan yang sistematis dari pada sejumlah obyek, gagasan, buku atau benda-benda lain ke dalam kelas atau golongan tertentu berdasarkan ciri-ciri yang sama. Di dalam klasifikasi bahan pustaka dipergunakan penggolongan berdasarkan ciri tertentu. Misalnya oleh karena bentuk fisik yang berbeda, maka penempatan buku perpustakaan dipisahkan dari surat kabar, majalah, piringan hitam, microfilm dan slides. Ada pula penggolongan berdasarkan penggunaan bahan pustaka, seperti koleksi referens dipisahkan dari koleksi lain. Akan tetapi yang menjadi dasar utama penggolongan koleksi perpustakaan yang paling banyak dipakai adalah penggolongan isi atau subyek buku. Ini berarti buku-buku yang membahas subyek yang sama akan dikelompokkan bersama-sama. Dalam penempatan buku harus disesuaikan dengan tata letak buku yang benar agar terlihat rapi dan mudah dicari.

\section{Rumusan Masalah}

Berdasarkan observasi yang telah dilakukan di perpustakaan STIKOM Binaniaga, diperoleh data jumlah koleksi buku yang dimiliki sebanyak 1895, koleksi tersebut terbagi menjadi beberapa subjek, diantaranya: buku dengan subjek pengenalan komputer, buku dengan subjek basis data, buku dengan subjek pemrograman, buku dengan subjek aplikasi, buku dengan subjek hardware, buku dengan subjek bisnis, buku dengan subjek manajemen, buku dengan subjek sistem informasi, buku dengan subjek agama, buku dengan subjek matematika, buku dengan subjek algoritma, buku dengan subjek metode penelitian, buku dengan subjek textbook. Semua buku yang disebutkan ditempatkan pada rak yang berjumlah 36 rak. Adapun penempatan koleksi buku pada perpustakaan STIKOM Binaniaga, dilakukan dengan cara mengelompokkan koleksi berdasarkan subjek, namun dalam hal penentuan posisi dan urutan penempatan koleksi buku didasarkan pada rak yang tersedia. Kondisi seperti ini mengakibatkan petugas perpustakaan kesulitan dalam menempatkan buku kembali ke asalnya 
setelah ada yang meminjam, selain itu juga menyebabkan sulitnya petugas perpustakaan dan pengunjung melakukan pencarian buku. Tabel 1 menunjukkan jumlah buku koleksi yang dimiliki perpustakaan STIKOM Binaniaga.

Tabel 1 Subjek Buku dan kode rak buku

\begin{tabular}{|c|c|c|}
\hline Kode Rak Buku & Subjek Buku & Jumlah Buku \\
\hline Rak 01 & Pengenalan komputer & 54 \\
\hline Rak 02 & Algoritma & 58 \\
\hline Rak 03 & hardware & 78 \\
\hline Rak 04 & kewirausahaan & 18 \\
\hline Rak 05 & agama & 15 \\
\hline Rak 06 & Textbook & 209 \\
\hline Rak 07 & Sistem informasi & 95 \\
\hline Rak 08 & Software & 281 \\
\hline Rak 09 & Bisnis & 37 \\
\hline Rak 10 & Database & 147 \\
\hline Rak 11 & Bahasa & 34 \\
\hline Rak 12 & Metode penelitian & 60 \\
\hline Rak 13 & Jaringan & 111 \\
\hline Rak 14 & Manajemen & 86 \\
\hline Rak 15 & Matematika & 85 \\
\hline Rak 16 & Pemrograman & 315 \\
\hline Rak 17 & Kewarganegaraan & 81 \\
\hline Rak 18 & Sistem operasi & 131 \\
\hline
\end{tabular}

Dari uraian ini dapat diidentifikasi masalah penelitian sebagai berikut:

1. Pola penempatan buku belum tepat.

2. Pola dalam penentuan urutan posisi buku sesuai dengan subjek buku belum tepat.

\section{Maksud dan Tujuan}

Maksud penelitian :

Maksud dari penelitian ini adalah untuk Menerapkan metode algoritma genetika untuk optimasi penempatan buku di perpustakaan STIKOM Binaniaga

Tujuan Penelitian :

1. Memperoleh pola yang tepat untuk penempatan buku.

2. Memperoleh pola yang tepat untuk menentukan urutan posisi buku yang sesuai dengan subjek buku.

\section{Landasan Teori}

\section{Algoritma Genetika}


Algoritma genetika telah banyak diaplikasikan untuk penyelesaian masalah dan pemodelan dalam bidang teknologi, bisnis dan entertainment seperti optimasi, pemrograman otomatis, mechine learning, model ekonomi, model sistem imunisasi, model ekologis hingga interaksi antara evolusi dan belajar. Dalam bukunya, DE Goldberg mendefinisikan algoritma genetika sebagai algoritma pencarian yang didasarkan pada mekanisme seleksi alamiah dan genetika alamiah (Suyanto, 2005, hal. 5)

Secara singkat, pemetaan proses alamiah ke dalam proses komputasi algoritma genetika dapat dirangkum dalam tabel berikut ini.

Tabel 5. Pemetaan proses alamiah ke proses komputasi

\begin{tabular}{|l|l|}
\hline Proses alamiah & Proses komputasi \\
\hline Individu & Penyelesaian Masalah \\
\hline Populasi & Himpunan Penyelesaian \\
\hline Fitness/kebugaran & Kualitas penyelesaian \\
\hline Kromosom & Kode/refresentasi penyelesaian \\
\hline Gen & Bagian dari representasi penyelesaian \\
\hline Pertumbuhan & Pendekodean representasi penyelesaian \\
\hline Penyilangan & Operator genetika \\
\hline Mutasi & Operator genetika \\
\hline Seleksi Alam & $\begin{array}{l}\text { Menyeleksi penyelesaian masalah (sementara) } \\
\text { berdasarkan kualitasnya. }\end{array}$ \\
\hline
\end{tabular}

Algoritma genetika merupakan suatu metode heuristik yang dikembangkan berdasarkan prinsip genetika dan proses seleksi alamiah teori evolusi darwin. Proses pencarian penyelesaian atau proses terpilinnya sebuah penyelesaian algoritma ini berlangsung sama seperti terpilihnya suatu individu untuk bertahan hidup dalam proses evolusi (Zukhri, 2014, hal. 19)

Setelah skema pengkodean ditentukan, AG diinisialisasi untuk sebuah populasi dengan $\mathrm{N}$ kromosom. Gen-gen yang mengisi masing-masing kromosom dibangkitkan secara random, biasanya menggunakan distribusi seragam (uniform distribution). Masing-masing kromosom akan didekodekan menjadi individu dengan nilai fitness tertentu. Sebuah populasi baru dihasilkan dengan menggunakan mekanisme seleksi alamiah, yaitu memilih individu-individu secara proporsional terhadap nilai fitness-nya, dan genetika alamiah, yakni pindah silang dan mutasi. Sebuah pseducode pada gambar 1 dibawah ini memperlihatkan langkah-langkah AG.

\section{Metode Penelitian}

Metode pada penelitian ini menggambarkan metode eksperimen. Eksperimen dan penelitian ini bersifat analisis. Penelitian eksperimen adalah penelitian pembelajaran yang dilakukan secara sistematis, objektif dan juga terkontrol guna memprediksi kejadian-kejadian.

Dalam penelitian ini, ada beberapa tahapan yang akan dilakukan untuk mencapai hasil yang diharapkan. Gambar 1 merupakan skema rancangan penelitian yang menggambarkan urutan dari tahapan yang akan diterapkan pada permasalahan optimalisasi penempatan buku di rak buku. 


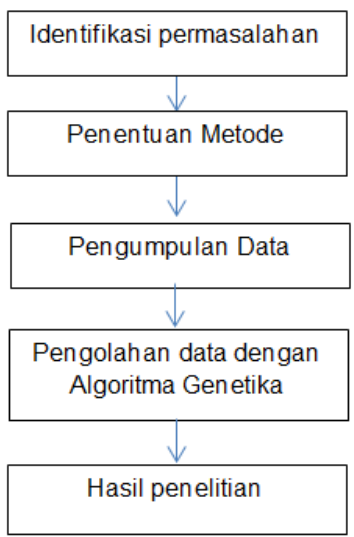

Gambar 1. Skema rancangan penelitian

\section{Sumber Data}

Data merupakan bagian terpenting dalam penelitian. Sumber data dari penelitian ini didapatkan dari perpustakaan. data-data yang dibutuhkan dari penelitian ini diantaranya adalah data jumlah buku persubjek, subjek buku, dan kode rak buku.

\section{Instrment Penelitian}

Penerapan analisis dalam penelitian ini menggunakan penelitian kuantitatif, dimana kebanyakan data diperoleh dari data perpustakaan berupa subjek buku dan data jumlah buku setiap subjek. Serta menggunakan matlab sebagai tools untuk mengolah data tersebut.

\section{Pengumpulan Data}

Teknik pengumpulan data dalam penelitian ini adalah Dokumentasi, yaitu data buku yang ada di perpustakaan STIKOM Binaniaga. Data yang digunakan adalah data koleksi buku perpustakaan sampai bulan Juli tahun 2016.

\section{Analisa Data}

Analisis data dalam penelitian ini dengan menggunakan Root Mean Square Error (RMSE). Untuk pengukuran menggunakan rata-rata erorr indikator kesalahan yang didasarkan pada total kuadratis dari simpangan antara hasil model dengan hasil observasi yang dapat didefinisikan menggunakan rumus RMSE (Root Mean Square Error) (Hyndman, 2014, hal. 29).

$$
R M S E=\sqrt{\frac{\sum_{i=1}^{n}\left(y-y^{\prime}\right)^{2}}{n}}
$$

Dimana:

$\mathrm{n}=$ Jumlah Data

$y=$ Variabel yang diamati

$y^{\prime}=$ Variabel yang di prediksi 


\section{Hasil Penelitian}

Variabel yang digunakan untuk optimasi penempatan buku di perpustakaan STIKOM Binaiaga adalah subjek buku,kode rak buku, dan jumlah buku. Dalam algoritma genetika, menggunakan parameter. Parameter algoritma merupakan salah satu bagian penting dalam penerapan algoritma genetika yang tidak mudah ditentukan dengan pasti. Tidak ada aturan yang pasti untuk menentukan parameter algoritma, baik probabilitas penyilangan, probabilitas mutasi, maupun ukuran populasi. Hal ini tidak terlepas dari prinsip algoritma genetika yang mengandalkan bilangan acak hampir dalam setiap langkahnya, mulai dari pembentukan populasi awal, proses penyilangan atau proses mutasi (Zukhri, 2014, hal. 49). Adapun parameter-parameter kontrol yang digunakan disesuaikan dengan masalah optimasi penempatan buku (Sukaton, 2011, hal. 19) adalah:

1) Popsize $=5$

2) Crossover_rate $(\mathrm{pc})=0,5$

3) Mutation_rate $(\mathrm{pm})=0,1$

Berdasarkan pada parameter diatas, maka dalam optimasi penempatan buku di perpustakaan akan mengalami evolusi yang berkelanjutan dimana akan menghasilkan generasi pada setiap evolusinya.

Untuk memilih kromosom yang tetap dipertahankan untuk generasi selanjutnya akan dilakukan proses seleksi yaitu kromosom yang mempunyai nilai fitness tertinggi akan memiliki peluang lebih besar untuk terpilih lagi pada generasi selanjutnya.

Dibawah ini hasil program algoritma genetika menggunakan matlab:

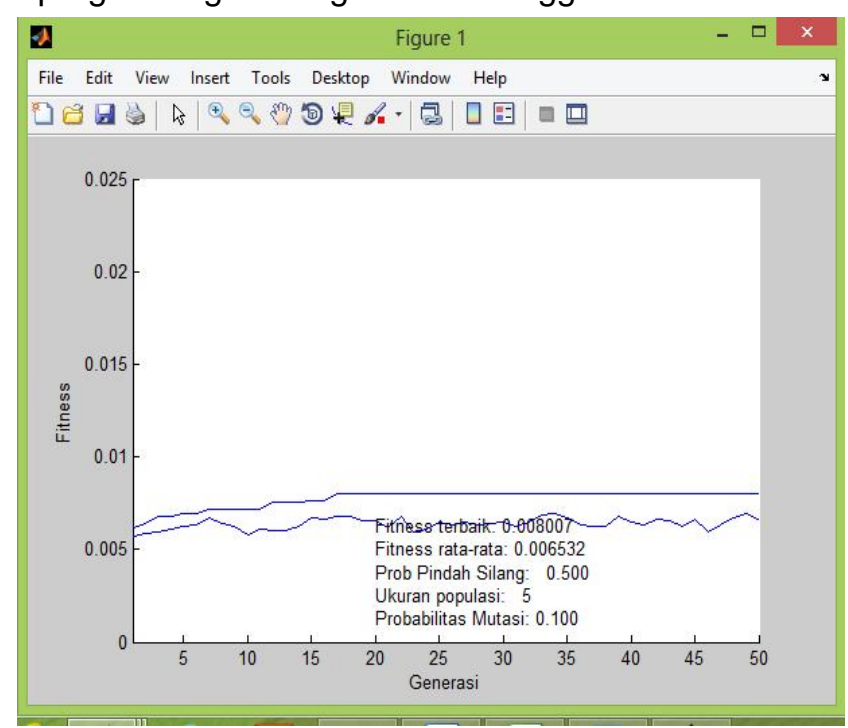

Gambar 2. Grafik hasil algoritma genetika

Pada gambar 8 , fitness terbaik yaitu 0.0080 , dengan probabilitas pindah silang 0.5 dan probabilitas mutasi 0.1. Ditunjukkan oleh variabel PosisiBuku pada gambar berikut: 


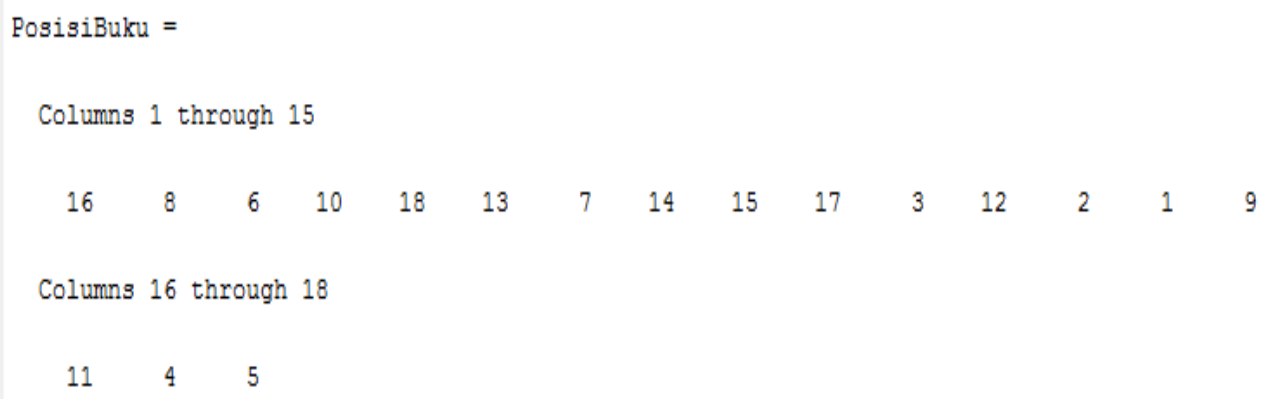

Gambar 3. Pola penempatan buku berdasarkan algoritma genetika

Dari gambar 3, terlihat bahwa solusi untuk penempatan buku berdasarkan jumlah buku adalah posisi 16-8-6-10-18-13-7-14-15-17-3-12-2-1-9-11-4-5, dengan nilai fitness 0.0080 . Iterasi ini berhenti jika sudah menemukan pola dengan jumlah buku terbanyak dan berurut dari jumlah terbesar sampai terkecil. Perbandingan hasil perhitungan manual dengan matlab sebagai berikut:

Tabel 3. Perbandingan hasil algoritma genetika

\begin{tabular}{|c|c|c|c|c|}
\hline \multirow{2}{*}{ Iterasi } & \multicolumn{2}{|c|}{ Perhitungan Manual } & \multicolumn{2}{c|}{ Perhitungan Matlab } \\
\cline { 2 - 5 } & Nilai Fitness & Pola & Nilai Fitness & Pola \\
\hline 1 & 0.0063 & $\begin{array}{c}1-14-15-7-8-9-18-13-5-6-3-2- \\
12-11-16-17-10-4\end{array}$ & 0.0078 & $\begin{array}{c}1-14-15-7-8-9-18-13-5-6- \\
3-212-11-16-17-10-4\end{array}$ \\
\hline 2 & 0.0064 & $\begin{array}{c}16-8-6-10-18-13-7-14-15-17-3- \\
12-2-1-9-11-4-5\end{array}$ & 0.0080 & $\begin{array}{c}16-8-6-10-18-13-7-14- \\
15-17-3-12-2-1-9-11-4-5\end{array}$ \\
\hline
\end{tabular}

Sebagaimana ditunjukkan pada tabel 29 , hasil perhitungan manual dengan perhitungan matlab yaitu nilai fitness berbeda tetapi pola penempatan sama. Dari perhitungan tersebut, untuk iterasi pertama untuk perhitungan manual dengan nilai fitness 0.0063 dan perhitungan dengan matlab dengan nilai fitness 0.0078 dan terdapat selisih yaitu 0.0015 . Sedangkan iterasi kedua untuk perhitungan manual 0.0064 dan perhitungan dengan matlab yaitu 0.0080 dengan selisih 0.0016 .

\section{Pembahasan}

Hasil yang diperoleh dari proses iterasi pada algoritma genetika sangat ditentukan oleh jumlah generasi dan parameter-parameter yang digunakan. Semakin banyak generasi akan semakin banyak kromosom yang bervariasi untuk dilakukan proses seleksi, crossover, dan mutasi dan hal ini menentukan nilai fitness yang beragam. Akan tetapi pada kenyataanya, tidak semua proses iterasi dapat dilakukan terus menerus karena kemungkinan menghasilkan nilai fitness yang buruk pun bisa terjadi. Setiap percobaan yang dilakukan akan menghasilkan nilai yang berbeda, hal ini dipengaruhi oleh penggunaan bilangan random yang banyak dalam proses algoritma genetika. Sementara bilangan random yang muncul tidak dapat dikendalikan. 
Maka dari itu generasi terbaik, dari seluruh generasi pada setiap percobaan akan dijadikan solusi dalam proses memperoleh pola yang tepat untuk menentukan urutan posisi buku yang sesuai dengan subjek buku.

Hasil dari perhitungan algoritma genetika, posisi buku yang tepat sesuai dengan nilai fitness terbaik adalah diurutkan sesuai dengan jumlah buku paling banyak. Berikut ini merupakan hasil analisis menggunakan algoritma genetika sesuai kode rak buku sebagaimana yang ditunjukkan pada tabel 30 .

Tabel 4. Posisi Buku berdasarkan Algoritma Genetika

\begin{tabular}{|c|c|c|}
\hline Kode Rak buku & Subjek Buku & Jumlah Buku \\
\hline Rak 01 & Pemrograman & 315 \\
\hline Rak 02 & Software & 281 \\
\hline Rak 03 & Textbook & 209 \\
\hline Rak 04 & Database & 147 \\
\hline Rak 05 & Sistem operasi & 131 \\
\hline Rak 06 & Jaringan & 111 \\
\hline Rak 07 & Sistem informasi & 95 \\
\hline Rak 08 & Manajemen & 86 \\
\hline Rak 09 & Matematika & 85 \\
\hline Rak 10 & Kewarganegaraan & 81 \\
\hline Rak 11 & Hardware & 78 \\
\hline Rak 12 & Metode penelitian & 60 \\
\hline Rak 13 & Algoritma & 58 \\
\hline Rak 14 & Pengenalan komputer & 54 \\
\hline Rak 15 & Bisnis & 37 \\
\hline Rak 16 & Bahasa & 34 \\
\hline Rak 17 & Kewirausahaan & 18 \\
\hline Rak 18 & Agama & 15 \\
\hline
\end{tabular}

Sebagaimana disajikan pada tabel 4 , hasil analisis menggunakan algoritma genetika posisi rak 01 diperoleh dengan subjek buku pemrograman dengan jumlah buku 315, rak 02 diperoleh dengan subjek buku software dengan jumlah buku 281, rak 03 diperoleh dengan subjek buku textbook dengan jumlah buku 209, rak 04 diperoleh dengan subjek buku database dengan jumlah buku 147, rak 05 diperoleh dengan subjek buku sistem operasi dengan jumlah buku 131,rak 06 diperoleh dengan subjek buku jaringan dengan jumlah 111, rak 07 diperoleh dengan subjek buku sistem informasi dengan jumlah buku 95, rak 08 diperoleh dengan subjek buku manajemen dengan jumlah buku 86, rak 09 diperoleh dengan subjek buku matematika dengan jumlah buku 85, rak 10 diperoleh dengan subjek buku kewarganegaraan dengan jumlah buku 81, rak 11 diperoleh dengan subjek buku hardware dengan jumlah buku 78, rak 12 diperoleh dengan subjek buku metode penelitian dengan jumlah buku 60, rak 13 diperoleh dengan subjek 
buku algoritma dengan jumlah buku 58, rak 14 diperoleh dengan subjek buku pengenalan komputer dengan jumlah buku 54, rak 15 diperoleh dengan subjek buku bisnis dengan jumlah buku 37, rak 16 diperoleh dengan subjek buku bahasa dengan jumlah buku 34, rak 17 diperoleh dengan subjek buku kewirausahaan dengan jumlah buku 18 dan rak 18 diperoleh dengan subjek buku agama dengan jumlah buku 15. Untuk membandingkan posisi buku berdasarkan algoritma genetika dengan posisi buku data awal, dilihat dari jumlah buku. Berikut ini merupakan posisi buku data awal sesuai kode rak buku dan jumlah buku sebagaimana yang ditunjukkan pada tabel 5 .

Tabel 5. Posisi buku data awal.

\begin{tabular}{|c|c|c|}
\hline Kode Rak Buku & Subjek Buku & Jumlah Buku \\
\hline Rak 01 & Pengenalan komputer & 54 \\
\hline Rak 02 & Algoritma & 58 \\
\hline Rak 03 & hardware & 78 \\
\hline Rak 04 & kewirausahaan & 18 \\
\hline Rak 05 & agama & 15 \\
\hline Rak 06 & Textbook & 209 \\
\hline Rak 07 & Sistem informasi & 95 \\
\hline Rak 08 & Software & 281 \\
\hline Rak 09 & Bisnis & 37 \\
\hline Rak 10 & Database & 147 \\
\hline Rak 11 & Bahasa & 34 \\
\hline Rak 12 & Metode penelitian & 60 \\
\hline Rak 13 & Jaringan & 111 \\
\hline Rak 14 & Manajemen & 86 \\
\hline Rak 15 & Matematika & 85 \\
\hline Rak 16 & Pemrograman & 315 \\
\hline Rak 17 & Kewarganegaraan & 81 \\
\hline Rak 18 & Sistem operasi & 131 \\
\hline
\end{tabular}

Sebagaimana disajikan pada tabel 4 dan 5 , untuk membandingkan posisi penempatan buku berdasarkan algoritma genetika dengan posisi buku data awal dilihat dari jumlah buku pada penelitian ini menggunakan RMSE, yaitu untuk membandingkan suatu harga hasil prediksi dengan harga original. Hasil harga prediksi yang baik ditunjukkan dengan nilai RMSE yang kecil karena RMSE yang kecil membuktikan bahwa harga hasil prediksi sangat mendekati harga originalnya. Berikut ini adalah hasil dari perhitungan Root Mean Square Error (RMSE) pada tabel 6 . 
Tabel 6. Hasil Perhitungan RMSE

\begin{tabular}{|c|c|c|c|}
\hline $\begin{array}{l}\text { Posisi subjek } \\
\text { buku }\end{array}$ & $\begin{array}{c}\text { Posisi subjek buku algoritma } \\
\text { genetika }\end{array}$ & $y-y^{i}$ & $\underset{\left.y^{\prime}\right)^{2}}{\text { Nilai hasil kuadrat }(y-}$ \\
\hline 54 & 315 & -261 & 68121 \\
\hline 58 & 281 & -223 & 49729 \\
\hline 78 & 209 & -131 & 17161 \\
\hline 18 & 147 & -129 & 16641 \\
\hline 15 & 131 & -116 & 13456 \\
\hline 209 & 111 & 98 & 9604 \\
\hline 95 & 95 & 0 & 0 \\
\hline 281 & 86 & 195 & 38025 \\
\hline 37 & 85 & -48 & 2304 \\
\hline 147 & 81 & 66 & 4356 \\
\hline 34 & 78 & -44 & 1936 \\
\hline 60 & 60 & 0 & 0 \\
\hline 111 & 58 & 53 & 2809 \\
\hline 86 & 54 & 32 & 1024 \\
\hline 85 & 37 & 48 & 2304 \\
\hline 315 & 34 & 281 & 78961 \\
\hline 81 & 18 & 63 & 3969 \\
\hline 131 & 15 & 116 & 13456 \\
\hline \multicolumn{3}{|c|}{ Jumlah } & 323856 \\
\hline
\end{tabular}

Sebagaimana ditunjukkan pada tabel 32 , terdapat nilai error dan nilai hasil kuadrat, nilai diperoleh dari nilai jumlah buku (variabel yang diamati) dikurangi jumlah buku algoritma genetika (variabel prediksi), untuk nilai absolut kuadrat diperoleh dari nilai error, pada nilai erorr nilai positif dan negatif tidak berpengaruh. Setelah diperoleh total hasil pengkuadratan kemudian dihitung uji akurasi dengan metode RMSE seperti berikut ini :

$$
\begin{aligned}
R M S E & =\sqrt{\frac{\sum_{i=1}^{n}\left(y-y^{\prime}\right)^{2}}{n}} \\
\text { RMSE } & =\frac{\sqrt{323856}}{19}=31.61574
\end{aligned}
$$

Berdasarkan hasil uji akurasi diketahui bahwa perhitungan jumlah data buku dengan menggunakan metode algoritma genetika mendapatkan nilai RMSE sebesar 31.61574. 


$$
\begin{aligned}
\text { Ketepatan prediksi } & =100-\text { RMSE } \\
& =100-31.61575 \\
& =68.38 \%
\end{aligned}
$$

Berdasarkan hasil uji akurasi diketahui bahwa perhitungan optimasi penempatan buku mendapatkan nilai RMSE 31.61574 dengan ketepatan prediksi sebesar $68.38 \%$. Setelah mendapatkan data yang sebenarnya dan mendapatkan hasil perhitungan dari algoritma genetika, maka perbandingan kesesuaian antara data sebenarnya dan hasil algoritma genetika mendapatkan hasil dimana terdapat 2 posisi subjek buku yang tidak berubah, yaitu subjek buku sistem informasi dan subjek buku jaringan. Berdasarkan pola tersebut penempatan sesuai dengan hasil algoritma genetika kurang tepat karena hasil selisih erorr $>0.01$

\section{Kesimpulan}

Berdasarkan pembahasan mengenai penerapan metode algoritma genetika untuk optimasi penempatan buku, maka dapat disimpulkan sebagai berikut:

1. Pola atau aturan yang dihasilkan dari proses algoritma genetika pada permasalahan penempatan buku memberikan solusi berupa nilai fitness terbaik berdasarkan kecenderungan pola data trend, dimana nilai fitness terbaik adalah 0.0080 , dengan pola penempatan buku yaitu 16-8-6-10-18-13-7-14-15-17-3-12-2-1-9-11-4-5.

2. Penempatan urutan posisi buku yang tepat sesuai dengan subjek buku menggunakan algoritma genetika dengan posisi buku berdasarkan jumlah buku adalah rak 01 dengan subjek buku Pemrograman, rak 02 dengan subjek buku software, rak 03 dengan subjek buku textbook, rak 04 dengan subjek buku Database, rak 05 dengan subjek buku Sistem Operasi, rak 06 dengan subjek buku Jaringan, rak 07 dengan subjek buku Sistem Informasi, rak 08 dengan subjek buku Manajemen, rak 09 dengan subjek buku Matematika, rak 10 dengan subjek buku Kewarganegaraan,rak 11 dengan subjek buku Hardware, rak 12 dengan subjek buku Metode Penelitian, rak 13 dengan subjek buku Algoritma, rak 14 dengan subjek buku Pengenalan Komputer, rak 15 dengan subjek buku Bisnis, rak 16 dengan subjek buku Bahasa, rak 17 dengan subjek buku Kewirausahaan, dan rak 18 dengan subjek buku Agama.

3. Hasil fitness yang sudah diperoleh, dianalisis menggunakan Root Mean Square Error (RMSE). Adapun hasil perhitungan analisis tersebut diperoleh nilai RMSE sebesar 31.61574, yang menunjukkan nilai error dari metode yang digunakan. Sementara tingkat ketepatan prediksi metode algoritma genetika sebesar $68.38 \%$. Nilai tersebut diperoleh dengan cara membandingkan pola penempatan buku yang dihasilkan menggunakan algoritma genetika dengan pola penempatan buku yang saat ini dipakai di perpustakaan STIKOM Binaniaga.

\section{Daftar Pustaka}

Basuki, S. (1993). Pengantar IImu Perpustakaan. Jakarta: PT Gramedia Pustaka Utama. 
Hasibuan, M. D., \& Lusiana. (2015). Pencarian Rute Terbaik Pada Travelling Salesman Problem (TSP) menggunakan algoritma genetika pada dinas kebersiihan dan pertamanan kota pekanbaru. Sains dan Teknologi Informasi.

Hyndman, R. J. (2014). Forecasting: Principles \& Practice. Australia: University of Western Australia.

Janata, A., \& haerani, E. (2015). Sistem Penjadwalan Outsourcing Menggunakan Algoritma genetika (Studi kasus : PT Syarikatama). Jurnal CorelT.

Kusnadi, A., \& santoso, d. s. (2015). Implementasi Algoritma Genetika Pada Penempatan Tugas Asisten Laboratorium Berbasis Web(Studi Kasus: LAB ICT Universitas Multimedia Nusantara). Ultimatics.

Loliancy, E. (2009). Analisis kinerja literatur. FISIP UI.

Putri, A. D., \& Astuti, I. M. (2014, Juni 3). Tata letak ilustrasi ditinjau dari segi proporsional ilustrasi pada buku pendamping tematik terpadu.

Ramdhani, G. (2014). Penerapan Algoritma Genetika untuk Optimalisasi Penyusunan Kemasan Produk di Coldstrage dengan Sistem First-In, First-Out.

Saputro, H. A., Mahmudy, W. F., \& Dewi, C. (2015). Implementasi algoritma genetika untuk optimasi penggunaan lahan pertanian. Jurnal Mahasiswa PTIIK.

Sihombing, R. S. (2014, April 2). Pemanfaatan algoritma genetika pada aplikasi penempatan buku untuk perpustakaan sekolah. VI, 113.

Siswono, T., \& Palgunadi, S. (2014). Analisa Kombinasi Algoritma Genetika dengan Algoritma Palgunadi untuk Penjadwalan Mata kuliah di Universitas sebelas Maret.

Sumarlinah. (2013). Perpustakaan Indonesia Menghadapi Era Open Access. Bogor: Perpustakaan Institut Pertanian Bogor.

Suyanto. (2005). Algoritma Genetika dalam Matlab. Yogyakarta: Andi Publisher.

Widodo, T. S. (2012). Komputasi Evolusioner. Yogyakarta: Graha IImu.

Zukhri, Z. (2014). Algoritma Genetika. Yogyakarta: Andi Publisher. 